\title{
Paradigma Al-Quran Kuntowijoyo
}

\author{
Kahar $^{1}$ \\ Institut Agama Islam Muhammadiyah Sinjai, Kabupaten Sinjai \\ Email: kaharstaim064@gmail.com
}

\begin{abstract}
Abstrak
Islam dalam bentuknya lengkap dengan pedoman beramal dalam segala segi kehidupan beragama. Al-Quran sebagai sumber primer ajaran Islam tak pernah sepi dari pemerhati yang terkesima dengan kekayaan dimensi yang dimiliki oleh al-Quran dari klasik hingga pada masa kontemporer, dari era agraris sampai pada era pasca industrial. Sehingga dapat dimengerti bahwa paradigma al-Quran yang dimaksudkan oleh Kuntowijoyo berarti suatu konstruksi pengetahuan yang memuat konsep-konsep dan saling terkait satu sama lainnya yang memungkinkan realitas dipahami sebagaimana al-Quran memahaminya.
\end{abstract}

\section{Kata kunci : Al-Qur'an, Kuntowijoyo}

\section{A. Pendahuluan}

Perubahan radikal terhadap pelbagai sektor kehidupan umat manusia sebagai dampak dari proyek akbar industrialisasi modern nampaknya cukup menggembirakan dan juga meresahkan. Menggembirakan karena kemajuan dalam teknologi telah memudahkan cara kerja manusia dari penggunaan tangan menuju mesin yang dapat meningkatkan mutu kehidupan yang lebih dinamis. Begitu juga, dengan kehadiran industrialisasi telah menjadi surga bagi pemilik modal dalam hegemoni dan dominasi alat-alat produksi. Namun, pada perkembangan selanjutnya, industrialisasi justru menjelma menjadi sebuah alat perbudakan baru yang meresahkan. Manusia yang semula merdeka telah mengalami degradasi, alienasi dan kebangkrutan derajat. Ia hanya menjadi elemen mekanisasi dan elemen otomatisasi teknologi dan tak lebih dari bagian mesin.

Transformasi sosial rupanya memang jalan yang paling manusiawi untuk mengubah sejarah kehidupan manusia. Peranan Islam semarak dipertanyakan dalam perwujudan transformasi dan cita-cita kemanusiaan. Dan ironisnya, peningkatan kesalehan pribadi dengan

\footnotetext{
${ }^{1}$ Dosen di STAI Muhammadiyah Sinjai
} 
penekanan pada wilayah simbolik keagamaan, nampaknya masih mendominasi alam bawah sadar umat Islam dan melupakan fungsi sentralnya sebagai agent of change terhadap perubahan sosial menuju masyarakat maju dan lebih humanis. Slogan 'kembali pada al-Qur'an dan Hadis' menggema atas nama pembaharuan. Namun, tak jarang agenda mereka terjebak pada wilayah-wilayah normatif dengan penerapan kerangka teoretis abad pertengahan yang lebih bernuansa truth claim (klaim kebenaran) dan dominasi pandangan hitam- putih ( $a$ dualistic worldview), atau salah-benar, islami-tidak islami yang justru berpotensi menciptakan konflik dan dehumanisasi baru. Dari sini, dibutuhkan gagasan-gagasan kreatif-inovatif mencerahkan bukan gagasan yang bersifat reaktif dalam merespon tantangan-tantangan umat Islam abad kontemporer.

Al-Quran sebagai sumber primer ajaran Islam tak pernah sepi dari pemerhati yang terkesima dengan kekayaan dimensi yang dimiliki oleh al-Quran dari klasik hingga pada masa kontemporer, dari era agraris sampai pada era pasca industrial. Kekuatan daya dorong sentripetal dan sentrifugal menjadikan al-Quran sebagai pusat gravitasi umat manusia pada umumnya. Pelbagai pendekatan telah ditawarkan, mulai dari linguistik, ushul fiqh, hermeneutik, sampai pada pendekatan integratif telah mengalami perkembangan signifikan dalam produksi dan reproduksi ide secara berkesinambungan. Namun tak dapat disangsikan bahwa al-Quran masih merupakan sebuah teks statis, dan tak mampu berbicara apa-apa tanpa refleksi manusia. Selanjutnya, interpretasi manusia tak berarti apa-apa tanpa aplikasi dan penerjemahan dalam realitas objektif dalam lingkup ruang dan waktu yang mengitarinya.

Mungkin, pemikiran Kuntowijoyo layak dipertimbangkan sebagai tawaran alternatif untuk menjawab kegelisahan umat Islam abad dua satu, sebab sejatinya realitas sosial selama ini kurang mendapat ruang dalam studi keislaman khususnya studi al-Quran. Kuntowijoyo mengandaikan ilmu pengetahuan islam bersifat rasional, empiris dan berasaskan pada wahyu dengan mencanangkan lima agenda reinterpretasi menuju reaktualisasi Islam. Baginya, perumusan paradigma al-Quran dalam sebuah kerangka teoritis sudah semakin mendesak untuk dijadikan sebagai referensi dalam menganalisis realitas.

\section{B. Sketsa biografi Kuntowijoyo}

\section{Mozaik kehidupan Kuntowijoyo}

Kuntowijoyo dikenal sebagai seorang sejarawan, budayawan dan sastrawan, sekaligus sebagai cendikiawan muslim. Terlahir di Bantul Yogyakarya pada tanggal 18 September 1943. Dari garis keturunannya, Kuntowijoyo berasal dari struktur kelas priyayi. 
Kakeknya seorang lurah, yang juga menjadi seniman, ulama, petani, pedagang, bahkan sebagai seorang tukang. Keluarga Kuntowijoyo juga terdiri dari orang-orang Muhammadiah dan Nahdlatul Ulama (NU). Dengan latar belakang yang unik, tidak heran jika ada yang menyebutnya sebagai seorang modernis, tradisionalis, reformis dan konservatif sekaligus ${ }^{2}$.

Masa kecil kuntowijoyo adalah masa ketika bergolaknya agresi Belanda; 1947 dan 1948. Pada tahun 1950, Kuntowijoyo masuk Sekolah Rakyat Negeri Ngawonggo dan menamatkan Sekolah Dasarya, pada tahun 1956. Sejak kecil, Kuntowijoyo aktif mengikuti kegiatan-kegiatan keagamaan dan kesenian di Surau dekat rumah dan mengenal budayawan Saribi Arifin dan M.Yusmanam seorang sastrawan nasional. Dan di surau itu pula, Kuntowijoyo mengenal dan terlibat dalam aktivitas organisasi masyarakat Muhammadiyah yang secara kebetulan surau tersebut milik Muhammadiah. Pada masa remaja, Kuntowijoyo menjalani kisahnya dengan berbagai ketertarikan terhadap dunia bacaan dan sastra. Kuntowijoyo rela menghabiskan sebagian besar waktunya di perpustakaan Masyumi yang sering ia kunjungi dan melahap hampir semua bahan bacaan yang tersedia. ${ }^{3}$

Setamat SMA tahun 1962, kuntuwijoyo diterima di Fakultas Sastra UGM dan diselesaikan pada tahun 1969. Ia mengajar di fakultas yang sama, sampai pada akhirnya mendapatkan kesempatan melanjutkan studi di The University of Connecticut USA hingga memperoleh M.A tahun 1974. Dan di Columbia University sampai meraih gelar Ph.D Ilmu Sejarah (1990) dengan judul disertasi "Social Change in an Agrarian Society: Madura 18501940”. Jabatan Guru Besar Ilmu Sejarah pada Fakultas Ilmu Budaya UGM diterimanya pada tahun 2001, melalui pidato pengukuhan berjudul "Periodisasi Sejarah Kesadaran Keagamaan Umat Islam Indonesia: Mitos, Ideologi, dan Ilmu” (21 Juli 2001). Profesinya sebagai dosen Jurusan Sejarah Fakultas Sastra (kini Fakultas Budaya) Universitas Gadjah Mada senantiasa mengedepankan gagasan intelektualnya selaku sejarawan. ${ }^{4}$

Namun sejak awal tahun 1990-an Kuntowijoyo menderita sakit yang tergolong langka di Indonesia. Ia mengidap radang selaput otak, yang dalam istilah medis disebut dengan meningo enshephslitis. Penyakit ini disebabkan oleh sejenis virus flu ganas yang menyerang selaput otak. Dampak dari penyakit tersebut adalah kemampuan otak untuk menggerakkan anggota tubuh menjadi terganggu. Kesulitan yang dialami oleh Kuntowijoyo

\footnotetext{
${ }^{2}$ M. Fahmi, Islam Transendental: Menelusuri Jejak-Jejak Pemikiran Islam Kuntowijoyo (Yogyakarta: Pilar Media, 2005) hlm. 29-30

${ }^{3}$ Ibid., hlm. 31-33

${ }^{4}$ Kuntowijoyo, Islam sebagai Ilmu: Epistomologi, Metodologi, dan Etika (Yogyakarta: Tiara Wacana, 2006) hlm. 135
} 
tersebut bukan merupakan sebuah halangan untuk tetap menulis. Hingga akhirnya pada tahun 1999, Kuntowijoyo mendapatkan penghargaan sastra bergengsi di Asia Tenggara yaitu SEA Write Award. Budayawan Emha Ainun Najib, dalam banyak kesempatan menyebut tulisan Kuntowijoyo setelah sakit menjadi sangat jernih dan mengagumkan. ${ }^{5}$

Kendati menjalani hidup dalam keadaan sakit, Guru Besar Ilmu Budaya UGM terus berkarya dan gagasan-gagasan brilian miliknya kini mulai dikaji oleh banyak kalangan. Beberapa gagasan Kuntowijoyo yang terkenal misalnya: ilmu sosial Profetik, Sejarah Sosial, Periodisasi Kesadaran Keagamaan Umat Islam, dan Objektifikasi Islam serta metode Strukturalisme Transendental, kini mulai banyak dikaji dan menjadi wacana tersendiri. Namun pada tanggal 22 Februari 2005, Kuntowijoyo kembali pada kehariban Tuhan dan jenazahnya dikebumikan di Makam Keluarga UGM di Sawitsari, Yogyakarta. ${ }^{6}$

\section{Karya-karya dan penghargaan}

Kuntowijoyo adalah sosok intelektual yang mumpuni. Ia menyandang sejumlah identitas dan gelar melekat pada dirinya. Diantaranya adalah sebagai emeritus Fakultas Ilmu Budaya Universitas Gadjah Mada Yogyakarta (UGM), sejarawan, budayawan, sastrawan, penulis kolumnis, intelektual muslim, aktivis, khatib dan sebagainya. karyanya lebih dari 50an buku. Ia juga seorang yang sangat menghargai kearifan budaya Jawa, rendah hati dan bisa bergaul dengan semua golongan, disamping sebagai seorang intelektual muslim yang jujur dan berintegritas. $^{7}$

Karya dalam bidang sastra berupa cerita pendek, novel, dan essai kebudayaan, muncul di majalah sastra, Horizon, Budaya Jawa, harian Kompas, dan Jihad. Cerpennya "Dilarang Mencintai Bunga-Bunga" memperoleh hadiah pertama dari majalah sastra (1968). Di tahun yang sama dramanya "Rumput-Rumput Danau Bento" memperoleh hadiah harapan dari BPTNI. Dan setelahnya, naskah dramanya berturut-turut "Tidak Ada Waktu bagi Nyonya Fatma", "Barda dan Cartas" (1972) dan “Topeng Kayu” (1973), mendapat hadiah dari Dewan Kesenian Jakarta. Sebuah novelnya "Pasar" mendapat hadiah dari Panitia Hari Buku. Novelnya "Kereta Api yang Berangkat Pagi Hari" dimuat di harian Jihad (1966). Sedang novelnya yang lain “Khotbah di Atas Bukit”, diterbitkan Pustaka Jaya (1976). ${ }^{8}$

\footnotetext{
${ }^{5}$ M. Fahmi, Islam Transendental: Menelusuri Jejak-Jejak Pemikiran Islam Kuntowijoyo (Yogyakarta: Pilar Media, 2005) hlm. 37

${ }^{6}$ Ibid., hlm. 37-38

${ }^{7}$ Ibid., hlm. 65 $161-162$

${ }^{8}$ Kuntowijoyo, Dinamika Sejarah Umat Islam Indonesia (Yogyakarta: Pustaka Pelajar, 1994) hlm.
} 
Selain sebagai sastrawan dan budayawan yang banyak menulis karya fiksi, dia juga pemikir Islam yang cerdas. Buku-bukunya, seperti Dinamika Sejarah Umat Islam Indonesia (1985), Identitas Politik Umat Islam (1987), Budaya dan Masyarakat (1987), Paradigma Islam, Interpretasi untuk Aksi (1991), Radikalisme Petani (1993), Demokrasi dan Budaya (1994), Metodologi Sejarah (1994), Pengantar Ilmu Sejarah (1995) Muslim tanpa Masjid (2001), dan Selamat Tinggal Mitos, Selamat Datang Realitas (2002), serta Intelektualisme Muhammadiah: Menyongsong Era Baru, sungguh mencerminkan kecerdasan, kejujuran dan integritasnya sebagai intelektual muslim dan menempati posisi istimewa di hati pembaca. ${ }^{9}$

\section{Islamisasi Ilmu Pengetahuan Vs Pengilmuan Islam}

Islamisasi Pengetahuan pertama kali diperkenalkan oleh Ismai'il Raji al-Faruqi dari lembaga pemikiran Islam Internasional (International Institute of Islamic Thought) di Amerika Serikat menjelang tahun 1980-an. Meskipun gagasan ini sebelumnya telah dicetuskan oleh Naquib Al-attas dari ISTAC Malaysia. Islamisasi pengetahuan mengandaikan umat Islam tidak serta merta menerima dan membeo begitu saja kepada sejumlah metodologi dari luar Islam, tetapi sejatinya dikembalikan pada poros ilmu pengetahuan, yaitu tauhid. ${ }^{10}$ Islamisasi Ilmu Pengetahuan berangkat pada semangat kembali kepada al-Quran yang merupakan basis ilmu pengetahuan ketika dihadapkan pada pencapaian objektivitas pengetahuan. ${ }^{11}$ Kuntowijoyo mengibaratkan epistomologi gerakan Islamisasi pengetahuan dengan gerakan balik dari konteks kepada teks (form Context to the text), untuk mencapai koherensi (keterkaitan) antara pengetahuan dengan iman. ${ }^{12}$

Kuntowijoyo merasa islamisasi pengetahuan merupakan sebuah kemajuan sebagai sebuah fase kesadaran akan urgensi ilmu pengetahuan modern dalam Islam. Tak dapat disangsikan, Islam tertinggal jauh dari peradaban lainnya sebagaimana Muhammad Abdus Salam nyatakan dan dikutip oleh Azyumardi Azra bahwa tidak diragukan saat ini di antara seluruh peradaban di planet ini, ilmu pengetahuan menempati posisi paling yang paling lemah

\footnotetext{
${ }^{9}$ M. Fahmi, Islam Transendental: Menelusuri Jejak-Jejak Pemikiran Islam Kuntowijoyo (Yogyakarta: Pilar Media, 2005) hlm. 67

${ }_{10}$ Kuntowijoyo, Islam sebagai Ilmu: Epistomologi, Metodologi, dan Etika (Yogyakarta: Tiara Wacana, 2006) hlm. 7

${ }^{11}$ Ahmad Zainil Hamdi, Menilai Ulang Gagasan "Islamisasi Pengetahuan" sebagai Blue Print Pengembangan Keilmuan UIN dalam Integrasi Ilmu dan Agama: Interpretasi untuk Aksi (Bandung: Mizan, 2005) hlm. 183

${ }^{12}$ Kuntowijoyo, Islam sebagai Ilmu: Epistomologi, Metodologi, dan Etika (Yogyakarta: Tiara Wacana, 2006) hlm. 8
} 
di Dunia Islam. $^{13}$ Menyikapi ketertinggalan Islam, Kuntowijoyo beranggapan bahwa Islamisasi pengetahuan tidak berarti penyangkalan secara total terhadap warisan intelektual peradaban-peradaban lain, termasuk dari peradaban barat, seperti yang dipahami oleh alFaruqi dan Ziauddin Sardar sebab posisi semacam itu tidak realistis karena rekonstruksi peradaban Muslim, termasuk rekonstruksi ilmu pengetahuan Islam, tidak dapat dilakukan dari sebuah ke-vacuum-an, tetapi di dalam ruang sejarah yang terbuka dan kompetitif dari pelbagai tawaran ide dan gagasan. Kuntowijoyo menganggap warisan ilmu pengetahuan Barat sebagai suatu khazanah yang dapat dimanfaatkan untuk sebuah kebutuhan, setelah proses seleksi dan adaptasi. $^{14}$

Islamisasi Pengetahuan, menurut Kuntowijoyo, sudah selayaknya ditinggalkan dan melangkah kepada "Pengilmuan Islam" sebagai tawaran alternatif untuk dikembangkan. Jika Islamisasi pengetahuan yang bergerak dari konteks ke teks, maka "pengilmuan Islam" mengandaikan gerak ke arah yang berlawanan, yaitu dari teks menuju konteks dengan perumusan norma-norma al-Quran menjadi konstruk teoritis dan faktual-aplikatif untuk mewujudkan misi rasional dan empiris Islam. ${ }^{15}$

\section{Alquran sebagai sebuah Paradigma}

Paradigma menjadi sebuah konsep popular yang dibicarakan oleh Thomas S. Khun. ${ }^{16}$ Istilah seperti kerangka teoritis (theoretical framework), kerangka konseptual (conceptual framework), kerangka pemikiran (frame of thinking), orientasi teoritis (theoretical orientation), sudut pandang (perspective), atau pendekatan (approach) memiliki pengertian yang kurang lebih sama dengan paradigma. Heddy Shri Ahimsa-Putra mendefenisikan paradigma sebagai seperangkat konsep yang berhubungan satu sama lain secara logis membentuk sebuah kerangka pemikiran yang berfungsi untuk memahami, menafsirkan dan menjelaskan kenyataan atau masalah yang dihadapi. ${ }^{17}$

Sehingga dapat dimengerti bahwa paradigma al-Quran yang dimaksudkan oleh Kuntowijoyo berarti suatu konstruksi pengetahuan yang memuat konsep-konsep dan saling

\footnotetext{
${ }^{13}$ Azyumardi Azra, Reintegrasi Ilmu-Ilmu dalam Islam dalam Integrasi Ilmu dan Agama: Interpretasi untuk Aksi (Bandung: Mizan, 2005) hlm. 203

${ }_{14}$ A.E.Priyono, Periferalisasi, Oposisi, dan Integrasi Islam di Indonesia: Menyimak Pemikiran DR.Kuntowijoyo dalam Paradigma Islam: Interpretasi untuk Aksi (Bandung: Mizan, 1993) hlm. 38-38

15 Kuntowijoyo, Islam sebagai Ilmu: Epistomologi, Metodologi, dan Etika (Yogyakarta: Tiara Wacana, 2006) hlm. 1

${ }^{16}$ Lihat Thomas S. Khun, The Structure of Scientific Revolutions (Chicago: University of Chicago Press, 1970) hlm. 43

17 Heddy Shri Ahimsa-Putra, Paradigma Profetik-Mungkinkah? Perlukah?, makalah yang disampaikan dalam 'Sarasehan Profetik 2011', diselenggarakan oleh Sekolah Pascasarjana UGM, di Yogyakarta, 10 Februari 2011.
} 
terkait satu sama lainnya yang memungkinkan realitas dipahami sebagaimana al-Quran memahaminya. ${ }^{18}$ Kuntowijoyo dalam hal ini mengandaikan rumusan teoritis (wawasan epistomologis) dan gambaran aksiologis yang dapat dijadikan sebagai pijakan awal dalam bertindak untuk mencapai cita-cita kemanusiaan.

Kuntowijoyo melihat bahwa para intelektual Islam masih terjebak pada wilayah normatif dan belum melangkah pada pengembangan norma-norma menjadi kerangkakerangka teori ilmu teoritis. Sebagai contoh, para penafsir memahami konsep fuqara dan masakin dengan tafsiran moral dan berujung pada kesimpulan bahwa kaum fakir dan miskin patut dikasihani dan diwajibkan untuk diberi zakat, infaq maupun sedekah kepada mereka. Dengan pendekatan teoritis, kaum fakir dan miskin sudah selayaknya diperjuangkan dengan memahami konsep tentang fakir dan miskin pada konteks yang lebih real, lebih faktual, sesuai dengan kondisi-kondisi sosial, ekonomi maupun kultural. ${ }^{19}$ Kuntowijoyo dalam hal ini, menawarkan umat Islam umumnya dan intetelektual muslim Islam khususnya terbiasa dengan analisis sosial untuk mengembangkan konsep-konsep dalam al-Quran.

Dialektika penafsir dengan al-Quran menciptakan pelbagai pendekatan yang ditawarkan dalam jagad raya ilmu tafsir. Kuntowijoyo dengan semangat progresifnya menawarkan pendekatan sintetik-analitik. Pendekatan ini manganggap bahwa pada dasarnya kandungan al-Quran terbagi menjadi dua bagian sentral, bagian pertama berisi konsep-konsep dan bagian kedua memuat kisah-kisah sejarah dan amtsal (perumpamaan). Dalam bagian pertama, didapati sejumlah istilah al-Quran yang merujuk pada pengertian-pengertian normatif yang khusus, doktrin-doktrin etik, aturan-aturan legal, dan ajaran keagamaan pada umumnya, baik itu konsep yang telah dikenal komunitas Arab saat al-Quran diturunkan maupun konsep etiko-religius yang ingin diperkenalkan. begitu pula, konsep yang bersifat abstrak seperti Allah, Malaikat, akhirat maupun konsep yang bersifat konkret dan dapat diamati (observable) seperti konsep fakir dan miskin, mustad'afin (kelas tertindas), mustakbirun (penguasa), mufsidun (koruptor) dan sebagainya. ${ }^{20}$

Bagian pertama bermaksud membentuk pemahaman yang komprehensif atau Weltanschaung (pandangan dunia) mengenai nilai-nilai ajaran Islam. Sedangkan dalam bagian kedua yang berisi kisah-kisah historis dan amtsal, al-Quran ingin mengajak dilakukannya

\footnotetext{
${ }^{18}$ Kuntowijoyo, Paradigma Islam: Interpretasi untuk Aksi (Bandung: Mizan, 1993) hlm. 327

${ }^{19}$ Ibid., hlm. 284

${ }^{20}$ Kuntowijoyo, Islam sebagai Ilmu: Epistomologi, Metodologi, dan Etika (Yogyakarta: Tiara Wacana, 2006) hlm. 12-13
} 
perenungan untuk memperoleh wisdom (hikmah) baik yang tersurat maupun yang tersirat. Jika dalam bagian konseptual diperkenalkan pelbagai ideal-type tentang konsep-konsep, maka dalam bagian yang berisi kisah dan amtsal kita diajak untuk mengenali arche-type tentang kondisi-kondisi yang universal, misalnya kisah kesabaran Nabi Ayyub, kezaliman Fir'aun, perjuangan pembebasan Nabi Musa dan lain sebagainya. ${ }^{21}$ Pemahaman pesan-pesan al-Qur'an dengan cara ini, disebut oleh Kuntowijoyo sebagai pendekatan sintetik, dengan mensitesiskan penghayatan dan subjektivitas penafsir dengan ajaran normatif al-Quran yang bersifat objektif yang memunculkan transformasi psikologis penafsir sampai pada tahap transformasi kemasyarakatan. $^{22}$

Pendekatan sintetik-analitik yang dimaksudkan Kuntowijoyo adalah menganalisis konsep-konsep normatif al-Quran menjadi sebuah konstruk teoretis kemudian diterjemahkan pada level objektif di masyarakat yang tentunya dapat diamati (observable). Elaborasi terhadap konstruk teoritis al-Quran inilah yang pada akhirnya merupakan Qur'anic theory building yang memunculkan paradigma al-Quran. Dan dengan paradigma inilah menurut Kuntowijoyo dapat difungsikan sebagai perspektif al-Quran dalam rangka memahami realitas. ${ }^{23}$ Cita-cita transformasi sosial dengan pendekatan sintetik-analitik Kuntowijoyo memiliki kesamaan dengan model tafsir transformatifnya Moeslim Abdurrahman dengan penelusuran pada tiga wilayah interpretasi, yakni: (1) memahami konstruk sosial. (2) membawa konstruk itu berhadapan dengan interpretasi teks (al-Qur'an), dan (3) hasil penghadapan konstruk sosial dan model ideal teks diwujudkan dalam aksi transformasi sosial. $^{24}$

\section{E. Strukturalisme Transendental}

Setelah paradigma al-Quran dirumuskan, lebih lanjut Kuntowijoyo menawarkan pendekatan alternatif yaitu Strukturalisme transendental yang dimaksudkan sebagai pisau analisa dalam memahami realitas. Tentu saja dengan adanya pengakuan mengenai adanya ide murni yang sumbernya berada di luar diri manusia yaitu "wahyu", 25 atau suatu konstruk tentang struktur nilai-nilai yang berdiri sendiri dan bersifat transendental. Kuntowijoyo

\footnotetext{
${ }^{21}$ Ibid., hlm. 13-14

${ }^{22}$ Ibid., hlm 14

${ }^{23}$ Ibid., hlm. 16
}

${ }^{24}$ Moeslim Abdurrahman, Islam Sebagai Kritik Sosial (Jakarta: Erlangga, 2003) hlm. 116

${ }^{25}$ Dalam QS: 69: 40-42, Allah berfirman "Sesungguhnya al-Quran itu adalah benar-benar wahyu (Allah yang diturunkan kepada) Rasul yang mulia, dan Al-Quran itu bukanlah perkataan seorang penyair. Sedikit sekali kamu kepadanya. Dan bukan perkataan tukang tenun. Sedikit sekali kamu mengambil pelajaran dari padanya". 
menegaskan dalam hal ini bahwa al-Quran harus dipahami sebagai sebuah bangunan ide yang transcendental, sebuah orde, atau system yang otonom dan sempurna. Dan di sisi lain, alQuran juga dapat dianggap sebagai suatu dokumen historis karena hampir setiap pernyataannya mengacu kepada peristiwa-peristiwa aktual sesuai dengan konteks sejarahnya ketika ia diturunkan. Namun, menurut Kuntowijoyo pesan utama al-Quran sejatinya bersifat transcendental, dalam arti melampaui zaman. ${ }^{26}$

Menyikapi hal ini, dengan metode struktur transcendental Kuntowijoyo, diandaikan sebagai metode yang mampu mengangkat atau mentransendensikan teks al-Quran dari konteksnya, yaitu dengan mentransendensikan makna tekstual dari penafsiran kontekstual berikut bias-bias historis tertentu akibat keterbatasan situasi historisnya. Kuntowijoyo juga menyatakan kekhawatirannya kepada para penafsir yang dibatasi oleh segala warisan historis umat Islam klasik. Meski membantu dalam memperkaya perspektif namun perspektif ataupun penafsiran tertentu tak lepas dari bias-bias karena keterbatasan historisnya. ${ }^{27}$ Pernyataan Kuntowijoyo juga mengindikasikan kemungkinan terjebak pada bias-bias kontemporer, namun Kuntowijoyo menganggap bahwa bias-bias kontemporer bersifat positif dalam meneropong masa ketika al-Quran diturunkan. ${ }^{28}$

Kuntowijoyo dalam hal ini mengindahkan penafsiran kontekstual, mengingat alQur'an tak lepas dari konteks historis yang mengikatnya atau dalam bahasa Nashr Hamid Abu Zaid, sebagai produk budaya (muntaj al-saqafi). ${ }^{29}$ Begitu juga dengan defenisi yang dirumuskan oleh tokoh hermeneutika liberatif Farid Esack yang memaknai al-Quran sebagai wahyu yang diturunkan dalam rangka merespon berbagai peristiwa yang terjadi. ${ }^{30}$ Sedangkan Ali al-Wardi menganggap bahwa mukjizat terbesar Nabi Muhammad adalah transformasi sosial (islah al-ijtima'i) dalam memerangi segala bentuk ketidakadilan, eksploitasi dan kebangkrutan etika kemanusiaan. ${ }^{31}$ Al-Wardi lebih lanjut mengkritisi doktrin i'jaz al-Qur'an pada keindahan bahasa dan sastra al-Qur'an dan mengabaikan nilai-nilai substantif atau pesan di balik teks. Sebab sejatinya wahyu al-Qur'an berdialog sesuai dengan bahasa dan kapabilitas

\footnotetext{
${ }^{26}$ Kuntowijoyo, Paradigma Islam: Interpretasi untuk Aksi (Bandung: Mizan, 1993) hlm. 331

${ }^{27}$ Ibid., hlm. 332

28 Ibid

${ }^{29}$ Nasr Hamid Abu Zaid, Mafhum al-Nas: Dirasah fi Ulm al-Qur'an (Beirut: al-Markaz al-Saqafi al-
} Arabi, 2000) hlm. 24

${ }^{30}$ Farid Esack, Qur'an, Liberation and Pluralisme: An Islamic Perspective of Interreligous Solidarity against Oppression (London: One World Oxford, 1997), hlm 54.

${ }^{31}$ Ali al-Wardi, Usturah al-Adab al-Rafi' (Beirut: Dar Kufan, 1994) hlm. 140 
keilmuan Arab semasa al-Quran diturunkan. ${ }^{32}$ Budaya tekstualitas, pemujaan metodologi tafsir klasik dan pengabaian realitas empiris menjadi kegelisahan tersendiri bagi al-Wardi.

Sikap pragmatis menurut Kuntowijoyo terkadang diperlukan untuk memenuhi kebutuhan situasional masyarakat Islam dalam mengaktualisasikan misinya sebagai wakil Tuhan di muka bumi. Namun sebelum melangkah terlebih jauh, perumusan paradigma alQuran menjadi sebuah kebutuhan yang sangat mendesak untuk kemaslahatan umat islam kontemporer bahkan umat manusia secara umum untuk menciptkan peradaban. Kuntowijoyo merasakan keprihatinan terhadap kekuatan dan pengaruh ilmu pengetahuan yang berujung pada tindakan destruktif, mengancam kehidupan manusia dan peradabannya. Islam diharapkan mampu menjadi tawaran alternatif dalam bidang ilmu pengetahuan. ${ }^{33}$

Terkait dengan konsep al-Qur'an, problem akademis yang dialami oleh Kuntowijo juga pernah menimpa Amin al-Khuli, Bapak tafsir sastra al-Qur'an. Al-Khuli mengedepankan perumusan konsep-konsep al-Qur'an sebagaimana konsep tersebut dipahami oleh masyarakat Arab semasa al-Quran diturunkan. ${ }^{34}$ Hal itu di dilakukan sebagai langkah awal atau pijakan menuju transformasi sosial-kemasyarakatan. Al-Khuli menegaskan secara eksplisit dalam bukunya al-Jundiyah wa al-Silm yang dikutip oleh Ahmad Muhammad Salim bahwa: ${ }^{35}$

Islam sejatinya memiliki dorongan transformatif yang disebabkan oleh perjumpaannya dengan pelbagai problema sosial-kemasyarakatan. al-Qur'an mendokumentasikan proses transformasi sosial dalam lika-liku perjalanan sejarahnya. Sehingga peranan Rasio/akal manusia menjadi amat sedemikan penting dalam mengkondisionalkan dinamika ruang dan waktunya.

Upaya al-Khuli mendialogkan teks al-Qur'an dengan realitas empiris, tercermin dalam perumusan pelbagai konsep al-Qur'an secara tematik dan amat terkait dengan problematika sosial-kemasyarakatan, seperti: harta benda (al-mal), puasa dan solidaritas

\footnotetext{
${ }^{32}$ Ibid., hlm 135

${ }^{33}$ Ibid., hlm. 336

${ }^{34}$ Kajian al-Khuli terhadap Al-Quran mengedepankan dua prinsip metodologis yaitu : studi sekitar Al-Quran (dirasah ma haula Al-Quran) dan studi tentang teks itu sendiri (dirasah fi Al-Quran nafsih). Kajian pertama sangat jelas diarahkan kepada investigasi latar belakang Al-Quran, dimulai dari proses pewahyuan, perkembangan dan sirkulasinya dalam masyarakat Arab sebagai obyek wahyu, beserta kodifikasi dan variasi cara baca : sebagai sebuah kajian yang kemudian lebih dikenal dengan 'Ulumul Quran. Kajian ini juga difokuskan pada aspek sosio-historis Al-Quran termasuk didalamnya situasi intelektual, kultural, dan geografis masyarakat Arab abad ke tujuh ketika Al-Quran diturunkan. Lihat selanjutnya, M. Nur Khalis Setiawan, Al-Quran kitab Sastra Terbesar, ( Yogyakarta : elSAQ press, 2005) hlm.12

${ }^{35}$ Ahmad Muhammad Salim, al-Islam al-Aqlani: Tajdid al-fikri al-dini inda Amin al-Khuli (Cairo: alHai'ah al-Mashriyah al-Ammah li al-Kitab, 2009) hlm. 81
} 
sosial, zakat dan lain sebagainya. al-Khuli mengutip sejumlah ayat dengan tema yang sama, kemudian diterjemahkan dalam refleksi-refleksi filosofis. Namun, tentu saja pendekatan yang digunakan oleh al-Khuli dalam menerjemahkan ke dalam realitas objektif berbeda dengan pendekatan Kuntowijoyo. Kombinasi Strukturalisme ${ }^{36}$ Levis-Strauss dengan Filsafat perennialisme Roger Garaudy menjadikan pendekatan Kuntowijoyo memiliki keunikan dan keunggulan tersendiri dalam operasionalisasi paradigma al-Qur'an.

\section{F. Ilmu Sosial Profetik}

Adalah suatu kenyataan bahwa masih banyak kelompok-kelompok sosial tak terserap dalam proses modernisasi. Kelompok sosial itu sering disebut sebagai 'orang-orang tersisih atau termarjinalkan' atau dengan sebutan 'dhu'afa' yakni renta ekonomi yang menjadikan mereka 'mustad'afin" yakni renta politik dan lemah harkat dari kemanusiaannya. ${ }^{37}$ Sementara itu, mayoritas pemuka agama cenderung memilih diam dan mempertahankan status quo bahkan sebagian dari mereka telah menciptakan sistem kelas baru sebagai elit agamawan dengan otoritas kebenaran dalam genggamannya.

Terlebih lagi metodologi ilmu sosial modern kurang mendapatkan ruang dalam ilmu-ilmu keislaman akibat sistem pendidikan yang dikotomis. Ernest Renan menyatakan bahwa dunia Islam dibatasi oleh kerangkeng besi yang mengkungkung kepala mereka, dan ironinya menganggap kungkungan itu telah mencapai pengetahuan pasti tanpa harus membuka diri untuk ide-ide baru. Dapat dipahami bahwa Renan mengandaikan adanya upaya pelonggaran konsep-konsep teologis dalam rangka pengembangan ilmu-ilmu keislaman. ${ }^{38}$ Demikian juga halnya dengan Muhammad Abduh, seorang tokoh tafsir modernis telah memperkenalkan dan menganggap humaniora (ilm ahwal al-basyar) sebagai ilmu yang sangat urgen dalam sebuah penafsiran. ${ }^{39}$

Mengacu pada perkembangan sosiologi agama modern, Bryan S Turner menemukan setidaknya ada tiga kelemahan mendasar dari sosiologi agama selama ini, yaitu (1) tidak lagi

${ }^{36}$ Strukturalisme pertama kali diperkenalkan dalam bidang linguistik oleh Ferdinand de Saussure tahun 1906, kemudian dalam antropologi oleh Claude Levi-Strauss tahun 1935. Ciri utama dari strukturalisme adalah totalitas (wholeness). Sedangkan Kuntowijoyo menggunakan Strukturalisme analitis dengan empat unsur penting yaitu: (1) inter-conectedness, seperti keterkaitan antara shalat dengan solidaritas sosial (2) innate structuring capacity (kekuatan pembentuk struktur paling dalam) seperti tauhid kemudian membentuk akidah, ibadah, akhlak, syariah, dan muamalah dan seterusnya (3) Binary Opposition (dua gejala yang saling bertentangan) seperti kepentingan tuhan dan manusia, badan dan ruh, orang kaya dan miskin dsb. (4) unsur sinkronis (unsur-unsur dalam satu waktu yang sama).

${ }^{37}$ Moeslim Abdurrahman, Islam Transformatif (Jakarta: Pustaka Firdaus, 1997) hlm. 37

${ }^{38}$ Bryan S Turner, Relasi Agama dan Teori Sosial Kontemporer (Yogyakarta: IRCiSoD, 2012) hlm.69

${ }^{39}$ Muhammad Abduh, al-A'mal al-Kamilah Li al-Imam al-Syekh Muhammad Abduh, ditahqiq oleh Muhammad Imarah (Cairo: Dar Syuruq, 2009) hlm. 10 
memainkan peranan atau tidak lagi ambil bagian dalam sebagian besar perdebatan teoritis sosiologi modern (2) fokus yang terlalu berlebihan pada subjektifitas pelaku sosial yang nampak dalam analisa mereka tentang keyakinan religious dsb. (3) fokus empiris pada wilayah yang terlalu sempit yaitu pada agama kristen, sehingga dapat dikatakan sosiologi agama tidak lain hanyalah bentuk representatif dari sosiologi Kristen. ${ }^{40}$

Kuntowijoyo melihat bahwa ilmu sosial saat ini mengalami masa stagnansi terlebih dalam dunia Islam. Bagi kuntowijoyo, ilmu sosial bukan sekedar mendeskripsikan fenomena sosial belaka, tetapi juga berupaya untuk mentransformasikannya. Sehingga ilmu sosial profetik, menjadi sebuah tawaran gagasan populer milik Kuntowijoyo untuk mencapai transformasi sosial berdasarkan cita-cita perubahan yang diidamkan oleh masyarakat, yaitu sebagai umat terpilih (the chosen people/khairu ummah). Ilmu sosial profetik pada dasarnya berdiri di atas tiga pilar yaitu, humanisasi/emansipasi (amar ma'ruf), liberasi (nahi munkar), dan transendensi (tu'minuna billah) yang diderivasikan dari misi historis Islam sebagaimana terkandung dalam ayat 110, surah Ali Imran:

"Engkau adalah umat terbaik yang diturunkan di tengah manusia untuk menegakkan kebaikan, mencegah kemungkaran (kejahatan) dan beriman kepada Allah"

Menjadi "The Choosen People" atau "Khairu Ummah" sebagaimana ayat sebutkan, Kontowijoyo menjabarkan dan mengelaborasi tiga pilar yang dapat dijadikan sebagai cita-cita ilmu sosial profetik sebagai berikut: ${ }^{41}$

\section{Humanisasi}

Dalam tema umum humanisasi dapat dilakukan penelitian tentang berbagai gejala sosial dan pemecahannya, yaitu dehumanisasi (objektivasi teknologis, ekonomis, budaya, atau Negara), agresivitas (agresivitas kolektif, dan kriminalitas), dan loneliness (privatisasi, individuasi). Ketiganya perlu penelitian teoritis, historis dan kasus. Manusia pada era industri atau pascaindustri sangat mudah untuk terjath dan kehilangan nilai-nilai kemanusiaannya. Sehingga diperlukan upaya untuk mengangkat kembali martabat manusia atau emansipasi manusia dan humanization. Dalam QS al-Tin (95): 5, 6 dikatakan bahwa orang dapat terjatuh

${ }^{40}$ Bryan S Turner, Relasi Agama dan Teori Sosial Kontemporer (Yogyakarta: IRCiSoD, 2012) hlm.

41 Kuntowijoyo, Islam sebagai Ilmu: Epistomologi, Metodologi, dan Etika (Yogyakarta: Tiara Wacana, 2006) hlm. 100-108. Lihat juga, Kuntowijoyo, Ilmu Sosial Profetik: Etika pengembangan ilmu-Ilmu Sosial dalam Re-strukturisasi Metodologi Islamic Studies Mazhab Yogyakarta (Yogyakarta: Suka Press, 2007) hlm. 104-112 
ke tempat paling rendah. Kemudian ayat ini mengecualikan orang-orang yang beriman dan amal saleh. $^{42}$

\section{Liberasi}

Teks al-Quran bisa diturunkan jadi empat hal: amal, mitos, ideologi dan ilmu. Islam sehari-hari adalah Islam amal yang harus selalu ada sepanjang zaman. Mitos sebagai system pengetahuan sudah ketinggalan zaman. Meskipun masih ada orang yang hidup dalam dunia mitis. Pada periode ideologi dengan menjadikan islam sebagai ideologi, seperti mengguritanya partai-partai yang beratasnamakan islam. Dan pada tahap terakhir adalah meninggalkan ideologi dan bergerak ke arah ilmu.

Kuntowijoyo dalam ilmu sosial profetiknya membidik empat sasaran liberasi. Yaitu, sistem pengetahuan, sistem sosial, sistem ekonomi dan sistem politik. Liberasi dari sistem sosial misalnya, menurut Kuntowijoyo, yaitu pembebasan dari sistem agraris menuju ke sistem sosial industrial. Perubahan itu ditegaskan kuntowijoyo sebagai the great transformation bagi umat. Begitu juga liberasi dari sistem ekonomi yaitu pembebasan umat dari kesenjangan ekonomi dan ketidakadilan. Pembebasan itu didasarkan pada dua ayat alQuran, yaitu QS al-Hasyr (59): 7 yang berbunyi "Supaya harta itu jangan beredar di antara orang-orang kaya di antara kamu”, dan QS al-Zukhruf (43): 32 yang berbunyi, "Apakah mereka (yang berhak) membagi-bagi rahmat Tuhanmu?" Karena itu, teori-teori dan penelitian empiris (Sejarah, kasus) baik di tingkat makro maupun mikro perlu dilakukan.

\section{Transendensi}

Krisis spiritual pada abad modern meniscayakan dedifferentiation (penyatuan kembali agama dengan aspek keduniaan) setelah mengalami sekularisasi agama atau differentiation pada fase modern dalam filsafat. Mengacu pada "teori spiral" yang mengatakan bahwa sejarah bergerak melingkar seperti suatu per, setiap kembali berputar seperti yang dulu tetapi selalu lebih tinggi dari semula. Bagi umat Islam sendiri, transendensi diartikan beriman kepada Allah Swt. Kedua unsur ilmu sosial Profetik (humanisasi, liberasi) harus mempunyai rujukan Islam yang jelas. Kuntowijoyo mengutip Fromm, bahwa siapa yang tidak menerima otoritas Tuhan akan mengikuti: (1) relativisme penuh (2) nilai tergantung pada masyarakat, sehingga nilai dari golongan dominan akan menguasai, dan (3) nilai tergantung pada kondisi biologis, sehingga sikap egoism, kompetisi, dan agresivitas adalah nilai-nilai kebajikan.

${ }^{42}$ QS al-Tin (95): 5, 6: Sesungguhnya kami telah menciptakan manusia dalam bentuk yang sebaikbaiknya (5) kemudian kami kembalikan dia ke tempat yang serendah-rendahnya (6) 
Karena itu menurut kuntowijoyo, sudah selayaknya umat Islam kembali kepada keimanan pada Allah setelah Tuhan dimatikan oleh para filosof semisal Marx dan Frued.

\section{G. Penutup}

Dari penjabaran makalah di atas, ada beberapa hal yang menarik untuk dicatat dari pemikiran Kuntowijoyo. Di antaranya adalah kesadaran untuk mengintegrasikan teori-teori dan metodologi Barat dalam rangka "enrichment" perbendaharaan pemikiran. Tapi peminjaman teori tersebut, Kuntowijoyo berupaya melakukan sintesis-sintesis kreatif dari pelbagai teori. Kemudian, sebagai seorang cendikiawan Muslim, Kuntowijoyo bertolak pada ajaran-ajaran Islam, terutama dari al-Quran, tanpa lewat tafsir-formal al-Quran. Sebab penafsiran dalam ruang dan zaman tertentu tak lepas dari bias-bias histioris yang melingkupinya. Kuntowijoyo berusaha menghayati makna yang terkandung dalam al-Quran, sebagaimana beliau mendedahkan "khairu ummah" dalam Ali Imran ayat 110 dengan menarik tiga pilar atau konsep penting pada pencapaian "The Chosen People" yaitu, humanisasi/emansipasi, liberasi dan transendensi. Kuntowijoyo bukannya tak berdasar, keterlibatan secara langsung dengan organisasi masyarakat Islam dengan penelitian intens pada sejarah dan sistem sosial dalam konteks keindonesian sehingga pada perumusan teori membuat namanya menjulang tinggi sebagai seorang cendikiawan nasional.

\section{DAFTAR PUSTAKA}

Abdurrahman, Moeslim. Islam Sebagai Kritik Sosial. (Jakarta: Erlangga, 2003) Islam Transformatif. (Jakarta: Pustaka Firdaus, 1997)

Abdullah, Amin Dkk Re-strukturisasi Metodologi Islamic Studies Mazhab Yogyakarta. (Yogyakarta: Suka Press, 2007)

Ahimsa-Putra, Heddy Shri. Paradigma Profetik-Mungkinkah? Perlukah?, makalah yang disampaikan dalam 'Sarasehan Profetik 2011', diselenggarakan oleh Sekolah Pascasarjana UGM, di Yogyakarta, 10 Februari 2011

al-Wardi, Ali. Usturah al-Adab al-Rafi'. (Beirut: Dar Kufan, 1994)

Azra, Azyumardi. Reintegrasi Ilmu-Ilmu dalam Islam dalam Integrasi Ilmu dan Agama: Interpretasi untuk Aksi, diedit oleh Zainal Bagir. (Bandung: Mizan, 2005) 
Fahmi, M. Islam Transendental: Menelusuri Jejak-Jejak Pemikiran Islam Kuntowijoyo. (Yogyakarta: Pilar Media, 2005)

Hamdi, Ahmad Zainil. Menilai Ulang Gagasan “Islamisasi Pengetahuan” sebagai Blue Print Pengembangan Keilmuan UIN dalam Integrasi Ilmu dan Agama: Interpretasi untuk Aksi (Bandung: Mizan, 2005)

Kuntowijoyo, Islam sebagai Ilmu: Epistomologi, Metodologi, dan Etika (Yogyakarta: Tiara Wacana, 2006)

, Paradigma Islam: Interpretasi untuk Aksi (Bandung: Mizan, 1993)

, Dinamika Sejarah Umat Islam Indonesia (Yogyakarta: Pustaka Pelajar, 1994)

Priyono, A.E. Periferalisasi, Oposisi, dan Integrasi Islam di Indonesia: Menyimak Pemikiran DR.Kuntowijoyo dalam Paradigma Islam: Interpretasi untuk Aksi (Bandung: Mizan, 1993)

Turner, Bryan S. Relasi Agama dan Teori Sosial Kontemporer (Yogyakarta: IRCiSoD, 2012)

Setiawan, M. Nur Khalis. Al-Quran kitab Sastra Terbesar, ( Yogyakarta: elSAQ press, 2005) 